Research Article

\title{
Effect of Lagenaria siceraria fruit extract (Bottle gourd) on hepatotoxicity induced by antitubercular drugs in albino rats
}

\author{
Satyajeet K. Funde, Jugalkishore B. Jaju*, Shrikant C. Dharmadhikari, Ganesh R. Pawar
}

Department of Pharmacology, Government Medical College, Latur, Maharashtra, India

Received: 29 August 2013 Accepted: 14 September 2013

*Correspondence to:

Dr. Jugalkishore B. Jaju, Email: jkb.jaju@gmail.com

(C) 2013 Funde SK et al. This is an open-access article distributed under the terms of the Creative Commons Attribution Non-Commercial License, which permits unrestricted non-commercial use, distribution, and reproduction in any medium, provided the original work is properly cited.

\begin{abstract}
Background: Anti TB drug induced hepatotoxicity has higher incidence in Indian population [11.5\%] than western population [4.5\%]. Antitubercular drug induced hepatotoxicity is mediated through oxidative and free radical damage to hepatocytes. Lagenaria siceraria [Bottle Gourd] is reported to have antioxidant and hepatoprotective activity. Hence in the present study we tested hepatoprotective and antioxidant activity of fruit extract of L. Siceraria in anti tubercular drug induced hepatotoxicity.

Methods: We administered antitubercular drugs alone and in combination with fruit extract of Lagenaria siceraria (EELS $100 \mathrm{mg} / \mathrm{kg}$ and EELS 200mg/kg) in healthy albino rats by oral route for 15 days. On 16th day blood collection for biochemical analysis is done by cardiac puncture. Biochemical markers used are serum transaminases (SGPT/SGOT), serum alkaline phosphatase [ALP], total bilirubin, total protein, superoxide dismutase [SOD] and malondialdehyde [MDA]. Liver is dissected for histopathological examinations.

Results: Groups that received EELS [100 mg/kg \& $200 \mathrm{mg} / \mathrm{kg}$ ], in combination with anti tubercular drugs, showed significant reduction [p value $<0.001$ ] in biochemical parameters for hepatotoxicity [SGOT, SGPT, ALP, Total bilirubin, Total protein] in comparison with group that received anti tubercular drugs alone. Combined treatment of EELS [100 mg/kg \& $200 \mathrm{mg} / \mathrm{kg}$ ] \& Anti tubercular drugs showed significant reduction in oxidative stress [SOD \& MDA, $\mathrm{p}<0.001]$ as compared to anti tubercular drug alone. Histopathological examination of liver showed grade I \& grade 0 changes in combination group while grade IV changes in group receiving anti tubercular drugs alone.

Conclusion: Ethanolic extract of Lagenaria siceraria fruit possesses significant hepatoprotective and antioxidant activity in antitubercular drugs induced hepatotoxicity.
\end{abstract}

Keywords: Hepatoprotective, Antioxidant, Lagenaria siceraria, Antitubercular drugs

\section{INTRODUCTION}

Drug Induced Liver Injury (DILI) is a potential complication with some medications. More than 1000 drugs ranging from NSAIDS to valproic acid have been implicated in drug induced liver injury rendering the treatment of drug induced liver disorder an important but challenging task for health care professionals. ${ }^{1}$ Drug induced liver injury is responsible for $5 \%$ of all hospital admissions and $50 \%$ of all acute liver failure. ${ }^{2}$ Drug induced hepatic damage is the most frequent reason that new therapeutic agents are not approved by the FDA and is the most common adverse drug reaction leading to the withdrawal of a drug from market. ${ }^{1}$
Thus, drug induced liver injury is a problem of increasing significance and has been a long-standing concern in the treatment of tuberculosis (TB) infection ${ }^{2}$ as the tuberculosis is a global pandemic and the incidence is rising because of Acquired Immunodeficiency Syndrome. The largest number of cases occurs in the Southeast Asia region which accounts for about a third of the global prevalence. Drug induced hepatotoxicity is a potentially serious adverse effect of antituberculosis treatment regimens containing isoniazid, rifampicin and pyrazinamide. A higher risk of hepatotoxicity has been reported in Indian patients than in their western counterpart, for example, a higher risk of $11.5 \%$ has been reported in Indian populations compared to $4.5 \%$ published in developed countries. 
Antitubercular drug induced hepatotoxicity is found to be mediated through oxidative damage and free radical damage to hepatocytes. In the last few years reactive oxygen and nitrogen species including free radicals have gained much clinical significance. Reactive species can cause oxidative damage to various biological molecules. They damage the cell membrane by a lipid peroxidation. Protein and DNA are also damaged by these reactive species. $^{3}$

Asymptomatic transaminase elevations are common during antituberculosis treatment but hepatotoxicity can be fatal when not recognized early and when therapy is not interrupted in time. Adverse effects diminish treatment effectiveness because they significantly contribute to nonadherence, eventually contributing to treatment failure, relapse or the emergence of drug-resistance. ${ }^{4}$

Lagenaria siceraria Standley fruit (Syn. L. vulgaris Ser., Cucurbita Lagenaria Linn., L. leucantha Rusbey, family Cucurbitaceae) commonly known as bottle gourd is widely used as a vegetable in India. ${ }^{5}$ It is a pubescent or trailing herb with bottle or dumb-bell shaped fruits. The fruit is traditionally used as medicine in India, China, European countries, Brazil, Hawaiian island. ${ }^{6}$ It is used as cardiotonic, aphrodisiac, liver and general tonic, antiinflammatory, expectorant and diuretic agent.

Recently, the antioxidant activity of ethanolic extract of Epicarp and fresh juice of $L$. siceraria fruit has been reported. Lagenin, a ribosome inactivating protein isolated from the seeds of $L$. siceraria possesses immunoprotective, antitumor, anti HIV and antiproliferative properties. Phytochemical screening of the fruit revealed the presence of fucosterol and compesterols flavonoids, cucurbitacins, saponins and polyphenolics, triterpenoids and C-flavone glycosides and ellagitannins. ${ }^{5}$

An attempt was made in the past few years to study whether Lagenaria siceraria has got any antioxidant and hepatoprotective property. Many in vitro and in vivo studies revealed that it possesses antioxidant and hepatoprotective properties. However as per available studies, there is no systematic work available to test the effect of Lagenaria siceraria on antitubercular drug induced hepatotoxicity in rat.

Hence present study is carried out to explore the hepatoprotective and antioxidant properties of ethanolic extract of Lagenaria siceraria in albino rats on biochemical and histopathological changes associated with antitubercular drug induced hepatotoxicity.

\section{METHODS}

\section{Experimental Animals}

The study protocol was duly approved by the Institutional Animal Ethics Committee (IAEC). Studies were performed in accordance with the CPCSEA guidelines. Healthy adult albino rats of either sex weighing between $150-200 \mathrm{~g}$ were used in experiment. The animals were acclimatized for ten days under laboratory conditions. The animals were fed with standard diet and water ad libitum under strict hygienic conditions.

\section{Test Drug}

Ethanolic Extract of Lagenaria siceraria (EELS):

Ethanolic Extract of Lagenaria siceraria (Manufactured by Prashant Pharmaceutics Ltd. Gujarat, and MFG. Date: FEB 2012) was purchased from the company for the study.

Dose $-100 \mathrm{mg} / \mathrm{kg} /$ day p.o. and $200 \mathrm{mg} / \mathrm{kg} /$ day p.o ${ }^{5}$

Antitubercular drugs were used to induce hepatotoxicity in following doses.

1. Isoniazid (INH) Powder $7.5 \mathrm{mg} / \mathrm{kg} / \mathrm{d}$.

2. Rifampicin (RMP) Powder $10 \mathrm{mg} / \mathrm{kg} / \mathrm{d}$.

3. Pyrazinamide (PZA) powder $35 \mathrm{mg} / \mathrm{kg} / \mathrm{d}$.

All the drugs were obtained in pure powdered form from Macleods Pharmaceuticals Pvt Ltd and Themis Medicare Ltd, Mumbai, India. Drugs were given by oral route in normal saline.

\section{Sylimarin}

Sylimarin was obtained in pure powdered form from the Serum Institute of India Ltd, Pune, India. Drug was given by oral route dissolving in normal saline.

Dose used: $100 \mathrm{mg} / \mathrm{kg} / \mathrm{d}^{5}$

\section{Experiment Design}

A total of 30 animals were included in the study. The animals were divided into five groups (6 animals in each group) and respective drugs were given for 15 days as follows.

Group-I Vehicle control (Normal saline $1 \mathrm{ml}$ p.o.)

Group-II (INH $7.5 \mathrm{mg} / \mathrm{kg}+$ RMP $10 \mathrm{mg} / \mathrm{kg}+$ PZA 35 $\mathrm{mg} / \mathrm{kg}$, p.o.)

Group-III (INH $7.5 \mathrm{mg} / \mathrm{kg}+$ RMP $10 \mathrm{mg} / \mathrm{kg}+$ PZA 35 $\mathrm{mg} / \mathrm{kg}$, p.o. $)+$ Sylimarin $(100 \mathrm{mg} / \mathrm{kg})$.

Group-IV (INH $7.5 \mathrm{mg} / \mathrm{kg}+$ RMP $10 \mathrm{mg} / \mathrm{kg}+$ PZA 35 $\mathrm{mg} / \mathrm{kg}$, p.o. $)+\operatorname{EELS}(100 \mathrm{mg} / \mathrm{kg})$.

Group-V (INH $7.5 \mathrm{mg} / \mathrm{kg}+\mathrm{RMP} 10 \mathrm{mg} / \mathrm{kg}+\mathrm{PZA} 35$ $\mathrm{mg} / \mathrm{kg}$, p.o. $)+\operatorname{EELS}(200 \mathrm{mg} / \mathrm{kg})$. 


\section{Collection of blood and liver sample}

On $16^{\text {th }}$ day blood was collected by cardiac puncture under light ether anesthesia. First abdomen was opened by taking a midline incision. Then diaphragm was cut with precaution to expose beating heart. By using 24 gauge needles, blood was collected slowly from left ventricle. Blood was collected in plain bulb for biochemical analysis and sent to biochemical laboratory.

Liver was dissected by cutting surrounding attachments. After taking 2-3 small incisions on it, it was kept in 10\% formalin and sent for Histopathological investigation.

\section{Investigations}

\section{I) Biochemical Investigations}

The following biochemical parameters were used.

- Serum alanine aminotransferase (Colorimetric end-point method) $^{8}$

- Serum aspartate aminotransferase (Colorimetric end-point method) ${ }^{9}$

- Alkaline phosphatase (ALP) (p-nitrophenol method) ${ }^{9}$

- Serum total bilirubin (Jendrassik and Grof $)^{10}$

- Serum total protein (Biuret method) ${ }^{11}$

- Serum Superoxide dismutase (SOD) (Marklund and Marklund) ${ }^{12}$

- Serum Malondialdehyde (MDA) (Pasha and Sadasivadu $)^{13}$

- Histopathological Examination of Liver: The liver specimens were sent in $10 \%$ formalin for histopathological examination. Histopathological assessment of liver damage was done by using $\mathrm{H}$ and $\mathrm{E}$ staining, paraffin block method. ${ }^{14}$ Histological grading was done according to Batts and Ludwig grading system. ${ }^{15}$

\section{Statistical Analysis}

The results of data were analyzed by one way ANOVA followed by Tukey's multiple comparison test ("GraphPad Prism, version 5.00 for Windows, GraphPad Software, San Diego California USA, www.graphpad.com"). $\mathrm{P}$ value $<0.05$ was taken as statistically significant.

\section{RESULTS}

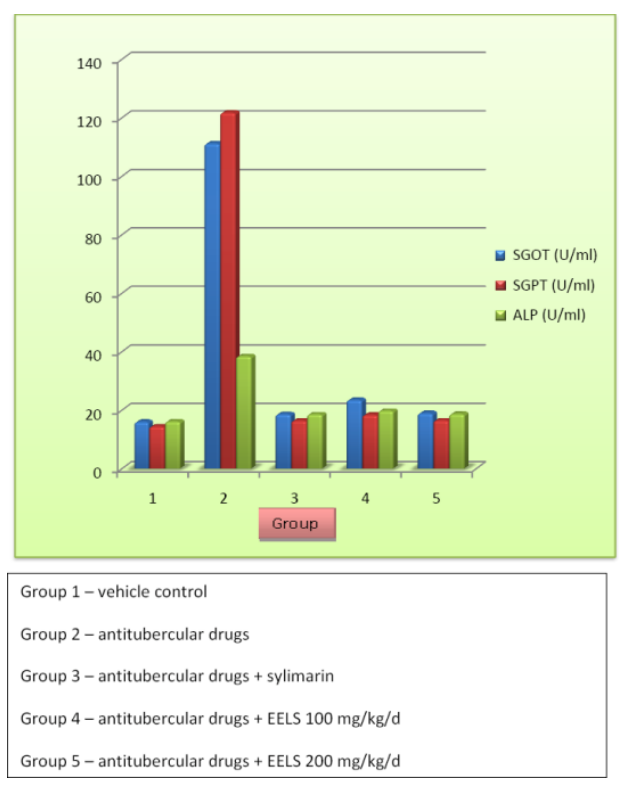

Figure 1: Effect of drugs on serum SGOT, SGPT, ALP.

Table 1: Effect of drugs on serum SGOT, SGPT and ALP.

\begin{tabular}{|c|c|c|c|c|}
\hline Gr. & Treatment & Sr. SGOT (U/ml) & Sr. SGPT (U/ml) & Sr. ALP (U/ml) \\
\hline 1 & Normal saline & $16.03 \pm 2.02^{\# \$}$ & $14.48 \pm 0.30^{\# \$}$ & $16.15 \pm 0.77^{\# \$}$ \\
\hline 2 & AKT & $111.2 \pm 2.49^{*}$ & $121.8 \pm 0.98^{*}$ & $38.45 \pm 0.96^{*}$ \\
\hline 3 & AKT + Sylimarin & $18.65 \pm 0.37$ & $16.45 \pm 0.26$ & $18.63 \pm 1.27$ \\
\hline 4 & AKT +EELS $100 \mathrm{mg} / \mathrm{kg}$ & $23.50 \pm 0.71$ & $18.42 \pm 0.40$ & $19.83 \pm 1.03$ \\
\hline 5 & AKT +EELS 200mg/kg & $18.98 \pm 0.45$ & $16.57 \pm 0.40$ & $18.73 \pm 0.48$ \\
\hline \multicolumn{2}{|c|}{$\begin{array}{l}\text { One way ANOVA followed by } \\
\text { Post hoc-Tukey's Multiple } \\
\text { comparison test }\end{array}$} & $\begin{array}{l}\mathrm{p} \text { value } *<0.001 \text { as } \\
\text { compared with groups } \\
1,3,4,5 ; \$>0.05 \\
\text { compared with groups } \\
3,5 ; \#<0.05 \text { compared } \\
\text { with group } 4\end{array}$ & $\begin{array}{l}\mathrm{p} \text { value } *<0.001 \text { as } \\
\text { compared with groups } \\
1,3,4,5 ; \$>0.05 \\
\text { compared with groups } \\
3,5 ; \#<0.05 \text { compared } \\
\text { with group4 }\end{array}$ & $\begin{array}{l}\mathrm{p} \text { value } *<0.001 \text { as } \\
\text { compared with groups } \\
1,3,4,5 ; \$>0.05 \\
\text { compared with groups } \\
3,5 ; \#<0.01 \text { compared } \\
\text { with group4 }\end{array}$ \\
\hline
\end{tabular}

AKT- Antitubercular drugs, all values are expressed in Mean \pm S.E.M. (Standard Error of Mean) 
Table 2: Effect of drugs on serum total bilirubin and total protein.

\begin{tabular}{|llll|}
\hline Gr. & Treatment & Sr. Total Bilirubin $(\mathbf{m g} / \mathbf{d l})$ & Sr. Total Protein $(\mathbf{m g} / \mathbf{d l})$ \\
\hline $\mathbf{1}$ & Normal saline & $0.39 \pm 0.016^{\# \$}$ & $7.03 \pm 0.229^{\# \$}$ \\
\hline $\mathbf{2}$ & AKT & $1.71 \pm 0.036^{*}$ & $4.40 \pm 0.186^{*}$ \\
\hline $\mathbf{4}$ & AKT + Sylimarin & $0.44 \pm 0.017$ & $6.58 \pm 0.289$ \\
\hline $\mathbf{5}$ & AKT +EELS 200 $\mathbf{m g} / \mathbf{k g}$ & $0.46 \pm 0.015$ & $6.11 \pm 0.208$ \\
\hline $\begin{array}{l}\text { One way ANOVA followed } \\
\text { by Post hoc-Tukey S Multiple } \\
\text { comparison test }\end{array}$ & $\begin{array}{l}\text { p value } *<0.001 \text { as compared with } \\
\text { groups } 1,3,4,5 ; \$>0.05 \text { compared } \\
\text { with groups } 3,5 ; \#<0.05 \text { compared } \\
\text { with group4 }\end{array}$ & $\begin{array}{l}\text { p value } *<0.001 \text { as compared with } \\
\text { groups } 1,3,4,5 ; \$>0.05 \text { compared } \\
\text { with groups } 3,5 ; \#<0.01 \text { compared } \\
\text { with group4 }\end{array}$ \\
\hline
\end{tabular}

Table 3: Effect of drugs on serum SOD and serum MDA.

\begin{tabular}{|c|c|c|c|}
\hline \multirow{2}{*}{ Gr. } & \multirow{2}{*}{ Treatment } & \multicolumn{2}{|c|}{ Biochemical parameters (mean \pm SEM) } \\
\hline & & Sr.SOD $(\mathrm{U} / \mathrm{ml})$ & Sr. MDA (nmoles/ml) \\
\hline 1 & Normal saline & $16.70 \pm 0.0^{\# \$}$ & $2.285 \pm 0.078^{\$ \#}$ \\
\hline 2 & AKT & $9.450 \pm 0.550 *$ & $5.512 \pm 0.172 *$ \\
\hline 3 & AKT + Sylimarin & $15.58 \pm 0.710$ & $2.498 \pm 0.079$ \\
\hline 4 & AKT +EELS 100 mg/kg & $13.89 \pm 0.561$ & $2.897 \pm 0.078$ \\
\hline 5 & AKT + EELS 200mg/kg & $16.14 \pm 0.561$ & $2.567 \pm 0.096$ \\
\hline \multicolumn{2}{|c|}{$\begin{array}{l}\text { One way ANOVA followed by Post } \\
\text { hoc-Tukey' Multiple comparison } \\
\text { test }\end{array}$} & $\begin{array}{l}\mathrm{p} \text { value } *<0.001 \text { as compared } \\
\text { with groups } 1,3,4,5 ; \$>0.05 \\
\text { compared with groups } 3,5 ; \\
\#<0.01 \text { compared with group } 4\end{array}$ & $\begin{array}{l}\mathrm{p} \text { value } *<0.001 \text { as compared } \\
\text { with groups } 1,3,4,5 ; \$>0.05 \\
\text { compared with groups } 3,5 ; \\
\#<0.001 \text { compared with group } 4\end{array}$ \\
\hline
\end{tabular}
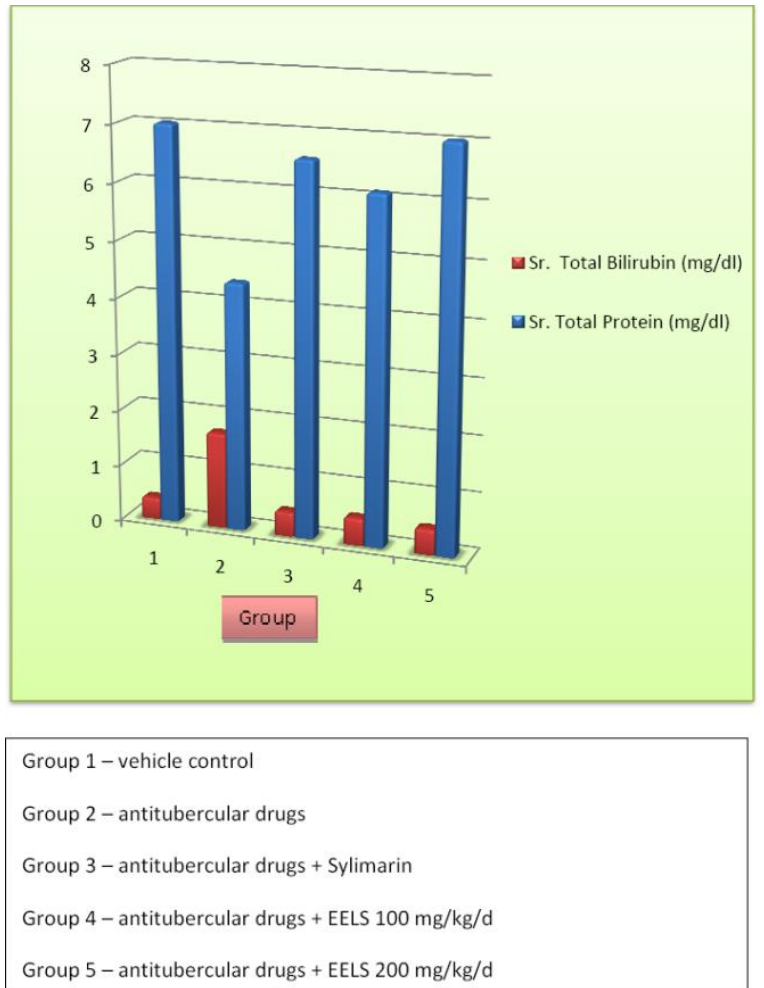

Figure 2: Effect of drugs on serum total bilirubin and total protein.
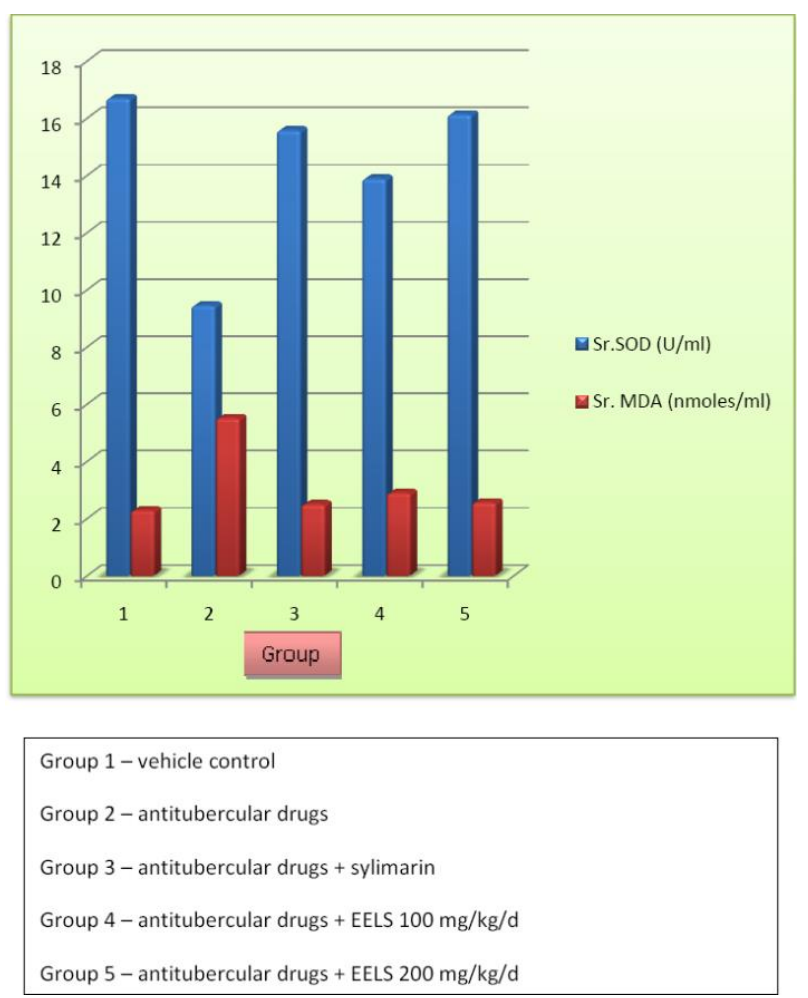

Figure 3: Effect of drugs on serum SOD and MDA 
Table 4: Effect of drugs on liver histopathology.

\begin{tabular}{|c|c|c|c|}
\hline Group & Treatment & $\begin{array}{l}\text { Histological } \\
\text { findings }\end{array}$ & Grade* \\
\hline 1 & $\begin{array}{l}\text { Control } \\
\text { (Normal } \\
\text { saline } 1 \mathrm{ml} \text { ) }\end{array}$ & $\begin{array}{l}\text { Section studied } \\
\text { shows normal } \\
\text { hepatic lobules } \\
\text { and sinusoids. }\end{array}$ & No grade \\
\hline 2 & AKT & $\begin{array}{l}\text { Section studied } \\
\text { shows fatty } \\
\text { change, } \\
\text { ballooning } \\
\text { degeneration, } \\
\text { portal triaditis. } \\
\text { At some places } \\
\text { also seen } \\
\text { bridging } \\
\text { necrosis. }\end{array}$ & Grade IV \\
\hline 3 & $\begin{array}{l}\text { AKT + } \\
\text { Sylimarin } \\
(100 \mathrm{mg} / \mathrm{kg} / \mathrm{d})\end{array}$ & $\begin{array}{l}\text { Section studied } \\
\text { shows } \\
\text { apparently } \\
\text { normal } \\
\text { hepatocytes } \\
\text { with minimal } \\
\text { ballooning } \\
\text { degeneration. }\end{array}$ & Grade 0 \\
\hline 4 & $\begin{array}{l}\text { AKT + EELS } \\
(100 \mathrm{mg} / \mathrm{kg} / \mathrm{d})\end{array}$ & $\begin{array}{l}\text { Section studied } \\
\text { shows Mild } \\
\text { perilobular } \\
\text { degeneration } \\
\text { and periportal } \\
\text { infiltration of } \\
\text { leucocytes. }\end{array}$ & Grade I \\
\hline 5 & $\begin{array}{l}\text { AKT + EELS } \\
(200 \mathrm{mg} / \mathrm{kg} / \mathrm{d})\end{array}$ & $\begin{array}{l}\text { Section studied } \\
\text { shows mild } \\
\text { ballooning } \\
\text { degeneration, } \\
\text { focal necrosis } \\
\text { absent. }\end{array}$ & Grade 0 \\
\hline
\end{tabular}

\footnotetext{
* =Batts and Ludwig grading system
}

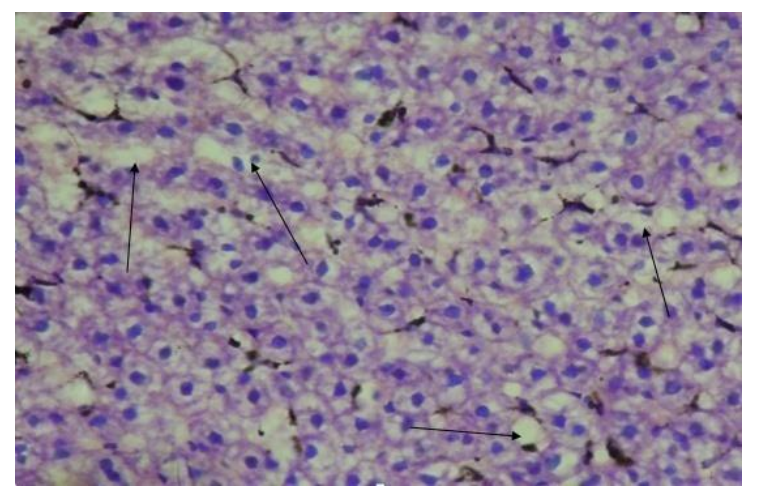

Figure 4: Histopathological changes of liver. H \& E stained section shows ballooning degeneration $(10 \mathrm{x})$ in rats fed with antitubercular drugs (group 2).

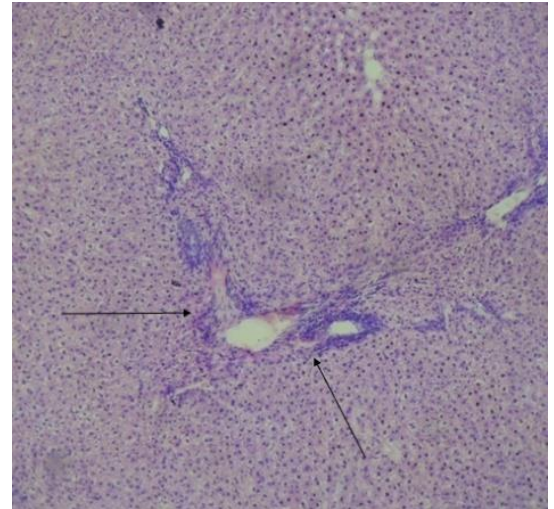

Figure 5: Histopathological changes of liver. H\& E stained section shows periportal infiltration $(10 \mathrm{x})$ in rats fed with antitubercular drugs + EELS $100 \mathrm{mg} / \mathrm{kg} / \mathrm{d}$ (group 4).

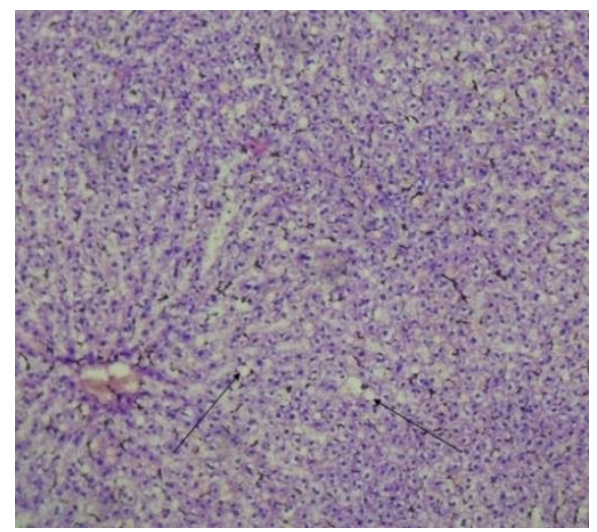

Figure 6: Histopathological changes of liver. H \& $\mathrm{E}$ stained section shows only mild degeneration $(10 \mathrm{x})$ in rats fed with antitubercular drugs + EELS 200mg/kg/d (group 5).

\section{DISCUSSION}

The liver may be considered as the most important organ in drug toxicity for two reasons: first it is functionally important site of absorption and the systemic circulation and second it is a major site of metabolism and elimination of foreign substances; but on the other hand these features also render it a preferred target for drug toxicity. Drug-induced liver injury (DILI) therefore poses a major clinical problem. ${ }^{16}$

Drug induced liver disease; a potential complication of some medication is a common cause of hepatic injury. More than 1000 drugs have been implicated in drug induced liver injury. Drugs mainly causing hepatotoxicity include antitubercular drugs, paracetamol, anticancer and antiHIV drugs. ${ }^{1,17}$

The recent growth in knowledge of free radicals and reactive oxygen species in biology is producing a medical revolution. Oxidative stress such as that due to free radical and /or reactive oxygen species causes organ injury. The growing body evidence indicate that oxidative 
stress plays an important role in pathogenesis of many clinical conditions. $^{3}$

Antioxidants both enzymatic and non enzymatic prevents free radical induced tissue damage by preventing the formation of radicals, scavenging them or by promoting their decomposition. ${ }^{18}$

Present study was conducted on albino rats of either sex to assess the effect of ethanolic extract of Lagenaria siceraria (EELS) on hepatotoxicity induced by antitubercular drugs. Various biochemical and histological parameters were used to assess the liver damage.

Concurrent administration of EELS along with antitubercular drugs. Significantly prevented derangement in various biochemical parameters as compared to group receiving antitubercular drugs alone.

During hepatic damage, cellular enzymes like SGPT, SGOT and ALP present in the liver cells leak into the serum, resulting in increased concentrations. ${ }^{19}$ Antitubercular drugs induced liver damage caused due to formation of toxic metabolites leads to elevation in SGPT, SGOT and ALP levels. In our study concurrent treatment with ethanolic extract of Lagenaria siceraria fruit significantly decreased the levels of SGPT, SGOT and ALP in serum which is an indication of hepatoprotective activity [Table 1, Figure 1].

SGOT is a mitochondrial enzyme released from heart, liver, skeletal muscle and kidney. Liver toxicity elevates the SGOT levels in serum due to the damage to the tissues producing acute necrosis, such as severe viral hepatitis \& acute cholestasis.

Antitubercular drugs induced liver damage caused due to formation of toxic metabolites is associated with mild to moderate elevation of transaminases. In the current study treatment of animals with ethanolic extract of Lagenaria siceraria significantly decreased the levels of SGOT in serum.

In case of toxic liver, alkaline phosphatase levels are very high, which may be due to defective hepatic excretion or by increased production of ALP by hepatic parenchymal or duct cells. ${ }^{20}$

In the current study treatment of animals with ethanolic extract of Lagenaria siceraria fruit significantly decreased the levels of ALP in serum.

Hepatocellular damage caused by antitubercular drugs increases the total bilirubin level and also decrease in total protein in serum due to the damage to the tissues. Since the Ethanolic extract of Lagenaria siceraria fruit showed decrease in total bilirubin and also increase in total protein level in serum of animals it possesses statistically significant hepatoprotective activity [Table 2, Figure 2].
This hepatoprotective activity of EELS further supported by histopathological findings showed by significant reduction in grades of liver damage. EELS $100 \mathrm{mg} / \mathrm{kg}$ dose showed mild perilobular degeneration and periportal infiltration of leucocytes (grade I) [Figure 5] and that of by EELS $200 \mathrm{mg} / \mathrm{kg}$ dose showed apparently normal histology with mild degenerative changes and absent necrosis (grade 0) [Figure 3].

Hepatoprotective activity of EELS noticed in the present study might be due to its property of reducing oxidative stress. The possible mechanism may be by prevention of process of lipid peroxidation and stabilization of the hepatocellular membrane which may be due to its various antioxidant constituents like flavonoids, vitamin $\mathrm{C}$, and beta carotene as well as due to the presence of phenolic compounds, terpenoid compounds and especially due the fucosterol and compesterol. ${ }^{5,21}$

In other studies Lagenaria siceraria showed hepatoprotective effect as it significantly prevented derangement of biochemical parameters. The results of the present study are in accordance with the findings of Deshpande et al, Lakshmi BVS et al and Elisha EE et al although they studied effect of EELS against carbon tetrachloride $(\mathrm{CCl} 4)$ induced liver damage.

We used our test drug EELS in two doses $(100 \mathrm{mg} / \mathrm{kg} / \mathrm{d}$ and $200 \mathrm{mg} / \mathrm{kg} / \mathrm{d}$ ). In both doses EELS showed a significant hepatoprotection by preventing derangement in biochemical parameters as well as histopathological changes when compared to group receiving antitubercular drugs.

EELS in both doses was as effective as the standard drug Sylimarin as there is no statistically significant difference between them though EELS $(200 \mathrm{mg} / \mathrm{kg})$ dose is more protective than EELS $(100 \mathrm{mg} / \mathrm{kg})$ dose.

Antioxidant property of EELS evidenced by prevention of derangement of SOD and MDA parameters as compared to group receiving antitubercular drugs [Table 3, Figure 3]. Reduced superoxide dismutase levels after antitubercular drugs administration to rats indicates that oxidative stress is involved in hepatotoxicity. In our studies, it reveals that treatment with ethanolic extract of Lagenaria siceraria increases the levels of SOD as compared to group 2 and possibly could reduce generation of free radicals and hepatocellular damage.

Group receiving antitubercular drugs have been shown to have higher Malondialdehyde, which is an oxidative stress parameter, maybe as a result of oxidative stress from the antituberculosis therapy. Antitubercular drugs induced liver injury has been associated with increased amount of lipid peroxidation. Ethanolic extract of Lagenaria siceraria supplementation in our study was effective in prevention of lipid peroxidation and subsequent rise in MDA levels as compared to group receiving antitubercular drugs. ${ }^{5,22}$ 
In the light of above reference and present observations made in the study, it can be concluded that ethanolic extract of Lagenaria siceraria fruit by way of inhibiting lipid peroxidation and by increasing antioxidant defence mechanism has a significant hepatoprotective action.

\section{CONCLUSION}

In the present study, treatment with EELS significantly reduced the toxicant elevated levels of above mentioned serum marker enzymes and increase in the levels of total protein. These changes supported by relevant histopathological findings.

Concurrent treatment with EELS prevented derangement in the both antioxidant parameters showing significant antioxidant activity.

Based on improvement in serum marker enzyme levels, antioxidant parameters, and histopathological studies, it is concluded that the ethanolic extract of Lagenaria siceraria fruit possesses hepatoprotective and antioxidant activities.

Funding: None

Conflict of interest: None declared

Ethical approval: The study was approved by the institutional animal ethical Committee.

\section{REFERENCES}

1. Jiwon K. An overview of drug-induced liver disease. US Pharm. 2005: 30(11):HS10-HS21.

2. Ostapowicz G, Fontana RJ, Schiodt FV, Larson A, Davron JT, Steven HB. Results of a prospective study of acute liver failure at 17 tertiary care centers in the United States. Ann Intern Med. 2002; 137: 947-954.

3. Sasaki M, John T. Oxidative stress and ischemiareperfusion injury in gastrointestinal tract and antioxidant, protective agents. J Clin Biochem Nutr. 2007; 40(1): 1-12.

4. Tostmann A, Boeree MJ, Aarnoutse RE, de Lange WC, van der Ven AJ, Dekhuijzen R. Antituberculosis drug-induced hepatotoxicity: concise up-to-date review. J Gastroenterol Hepatol. 2008 Feb; 23(2):192-02.

5. Deshpande JR, Choudhari AA, Mishra MR, Meghre VS, Wadodkar SG, Dorle AK. Beneficial effects of Lagenariasiceraria (Mol.) Standley fruit epicarp in animal models. Indian J Exp Biol. 2008 Apr; 46(4):234-42.

6. Saha P, Sen SK, Bala A, Muzumder UK, Haldar PK. Evaluation of anticancer activity of LS Aerial parts. Int. J. Cancer Res 2011; 7(3): 244-253.

7. Padma V, Suja V, Shyamala Devi C.S. Hepatoprotective Effect of Liv.52 on Antitubercular
Drug-induced Hepatotoxicity in Rats Fitoterapia 1998; 69(6): 520-22.

8. Reitman S, Frankel S. In vitro determination of transaminase activity in serum. Am J Clin Pathol1957; 28:56-60.

9. Bomers GN, McComb RB. Clin. Chem 1975; 21:1988-95.

10. Tolman KG, Rej R. Jendrassik - Grof Technique. In: Burtis CA, Alhwood ER editors. Tietz Textbook of Clinical Chemistry. $3^{\text {rd }}$ ed. W. B. Saunders Company; 1999. p. 1169-70.

11. Gornall AG, Bardawill CJ, David MM. Determination of serum proteins by means of the biuret reaction. J Biol Chem 1949; 177(2):751-66.

12. Marklund S, Marklund G. Involvement of the superoxide anion radical in the autoxidation of pyrogallol and a convenient assay for superoxide dismutase. Eur J Biochem1974; 47:469-74.

13. Pasha KV, Sadasivadu B. Intracellular content of thiol compounds, thiobarbituric acid reactive substances and gamma-glutamyl transpeptidase in rat brain during anoxia. Neurosci Lett 1984; 46:20914.

14. Gamble M. The Hematoxylins and Eosin. In: Bancroft JD, Gamble M editors. Theory and practice of Histological Techniques. $6^{\text {th }}$ ed. Churchill Livingstone Elsevier; 2008.p. 121-134.

15. Batts KP, Ludwig J. Chronic hepatitis an update on terminology and reporting. Am J Surg Pathol 1995; 19:1409-17.

16. Russmann S, Kullak-Ublick GA, Grattagliano I. Current concepts of mechanisms in drug-induced hepatotoxicity. Curr Med Chem. 2009; 16(23):304153.

17. Duseja A and Dhiman RK. Drug induced hepatotoxicity. Drugs bulletin 2000; 24:16-34.

18. Young IS, Woodside JV. Antioxidants in health and disease. J Clin Pathol 2001; 54(3):176-86.

19. Deb AC. Fundamentals of biochemistry, 7th ed. Kolkata, India: New Central Book Agency; 2002. p. 139-40.

20. Harsh Mohan. The liver, biliary tract and exocrine pancreas. In: Text book of pathology, Jaypee Brothers Medical Publishers (P) Ltd. New Delhi 2002; 4: 569-630.

21. Singh S, Gill N.S, Arora R. An updated review of Lagenaria siceraria. The Global Journal of Pharmaceutical Research 2012;1(2):378-87.

22. Fard MH, Bodhankar SL, Dikshit M. Cardioprotective activity of fruit of Lagenaria siceraria (Molina) standley on doxorubicin induced cardiotoxicity in rats. Int $\mathbf{J}$ Pharmacol 2008;4:46671.

doi:10.5455/2319-2003.ijbcp20131211

Cite this article as: Funde SK, Jaju JB,

Dharmadhikari SC, Pawar GR. Effect of Lagenaria siceraria fruit extract (Bottle gourd) on hepatotoxicity induced by antitubercular drugs in albino rats. Int $\mathbf{J}$

Basic Clin Pharmacol 2013;2:728-34. 